\title{
THE PROTECTION OF FOREIGN INVESTMENT AND THE HICKENLOOPER AMENDMENT
}

\author{
RICHARD B. LIILTCH $\dagger$
}

You can't dictate to people. If the United States threatens to take away aid under these conditions there is not a country in the world that would not tell us to go to hell.

\section{W. AvERELl HARRIMAN ${ }^{1}$}

The so-called "Hickenlooper Amendment," 2 added to the Foreign Assistance Act of $1962,{ }^{3}$ is a legislative manifestation of the belief that the threat to suspend foreign aid to countries which expropriate American property without just compensation is a sound and effective method of protecting private foreign investment. ${ }^{4}$ Since its enactment the amendment has been invoked just once, against Ceylon, ${ }^{5}$ with the result predicted by Governor Harriman. ${ }^{6}$ Nevertheless, congressional insistence that "it had been extremely useful in strengthening the hand of the U.S. Government in dealing with foreign governments that were tempted to expropriate U.S. property" " led to the amendment's further strengthening in $1963 .^{\circ}$ After a brief presentation of the original Hickenlooper Amendment and a consideration of the 1963 amendments thereto, this Article will evaluate its effectiveness to date.

+ Associate Professor of Law, Syracuse University. A.B. 1954, Oberlin College; LL.B. 1957, Cornell University; LL.M. (International Law) 1959, J.S.D. 1960, New York University. Member, New York Bar.

1 N.Y. Herald-Tribune, Jan. 7, 1964, p. 10, col. 8 (Int'1 ed.).

2 Named after Senator Hickenlooper who introduced a bill on the subject in 1962 and who, in 1963, acknowledged that "from a personal standpoint the heartwarming eulogies of the Hickenlooper amendment are appreciated." Hearings on S. 1276 Before the Senate Committee on Foreign Relations, 88th Cong., 1st Sess. 348 (1963) [hereinafter cited as Senate Hearings]. But Representative Hays apparently claims coparentage. "If you are going to rename that amendment, let us call it the AdairHays amendment." Hearings on H.R. 5490 Before the House Committee on Foreign Affairs, 88th Cong., 1st Sess. 1531 (1963) [hereinafter cited as House Hearings].

376 Stat. 260-61 (1962), 22 U.S.C. \$2370(e) (Supp. IV, 1962).

4 See generally Lillich, The Protection of Foreign Investment and the Foreign Assistance Act of 1962, 17 Rutgers L. REv. 405 (1963).

5 The United States suspended economic and technical assistance to Ceylon on February 8, 1963, following that country's nationalization without compensation of eighty-three gas stations and other properties belonging to two American oil companies. 48 Dep't State Bull. 328-29 (1963).

6 It has been reported that "Mrs. Bandaranaike angrily accused the American Government of trying to dictate terms and said, "Ceylon is not prepared to dance to the tune of the capitalist countries to obtain aid!" The Observer (London), Feb. 24,1963, p. 38 , col. 3 .

7109 Cong. REc. 20515 (daily ed. Nov. 12, 1963) (Senator Keating).

877 Stat. 386-87 (1963). The relevant provision is reported unofficially in U.S. Cone Cong. \& Ad. News 2936 (Jan. 5, 1964). 


\section{The Original Amendment}

On February 16, 1962, the governor of a Brazilian state cancelled the operating title of a subsidiary of IT\&T and ordered the expropriation of its properties. When he deposited as indemnity only 62/3-10 percent of what IT\&T considered the subsidiary's worth, the Department of State, although acknowledging Brazil's right to expropriate foreign property, asserted that the tendered compensation was "so far below book value that the valuation appears to have been made unilaterally." " Negotiations for additional compensation broke down almost immediately, and on March 1, 1962, Senator Russell Long warned the Senate that "we should not continue generous U.S. foreign aid at the same time that the aid's recipients are seizing, virtually without compensation, valuable property of those U.S. taxpayers who are paying for that very aid." 10 Within a week a halfdozen bills aimed at protecting private foreign investments by the threat to withhold public foreign aid funds were in the congressional hopper. ${ }^{11}$

Both President Kennedy ${ }^{12}$ and Secretary of State Rusk ${ }^{13}$ immediately opposed these bills as unwise and unnecessary. The Department of State, in a memorandum submitted to Congress, took the position that

the injection of the U.S. foreign assistance program into condemnation proceedings would at best advance the interests of the American citizen whose property is expropriated only marginally, and, on the other hand, it can seriously injure the vital U.S. national interests which the foreign assistance program is designed to further. ${ }^{14}$

Despite these pleas, Congress continued the debate on the bills during the spring. Finally, on May 8, 1962, Senator Hickenlooper proposed his amendment to the Foreign Assistance Act, which required the President to cut off foreign aid to any country taking American property, "without providing immediate and effective compensation . . as required by international law, justice, and equity . . . ."15

9 N.Y. Times, Feb. 18, 1962, p. 33, col. 2.

10108 CoNG. Rec. 3134 (1962).

11 Lillich, supra note 4, at $408 \mathrm{nn} .25$ \& 26.

12 N.Y. Times, March 8, 1962, p. 14, col. 8.

13 See, e.g., Hearings on S. 2996 Before the Senate Committee an Foreign Relations, 87th Cong., 2d Sess. 31 (1962).

14 Id. at 558.

15108 Cong. Rec. 7893 (1962). 
After a long debate and several modifications, ${ }^{16}$ the Hickenlooper Amendment was added to the Foreign Assistance Act of 1962, which the President signed into law on August 1, 1962. ${ }^{17}$ The amendment, section 620 (e) of the act, read as follows:

The President shall suspend assistance to the government of any country to which assistance is provided under this chapter when the government of such country or any governmental agency or subdivision within such country on or after January 1, 1962-(1) has nationalized or expropriated or seized ownership or control of property owned by any United States citizen or by any corporation, partnership, or association not less than 50 per centum beneficially owned by United States citizens, or (2) has imposed or enforced discriminatory taxes or other exactions, or restrictive maintenance or operational conditions, which have the effect of nationalizing, expropriating, or otherwise seizing ownership or control of property so owned, and such country, government agency or government subdivision fails within a reasonable time (not more than six months after such action or after August 1, 1962, whichever is later) to take appropriate steps, which may include arbitration, to discharge its obligations under international law toward such citizen or entity, including equitable and speedy compensation for such property in convertible foreign exchange, as required by international law, or fails to take steps designed to provide relief from such taxes, exactions, or conditions, as the case may be, and such suspension shall continue until he is satisfied that appropriate steps are being taken and no other provision of this chapter shall be construed to authorize the President to waive the provisions of this subsection. ${ }^{18}$

Although the amendment fairly bristles with interesting legal questions, ${ }^{19}$ for present purposes only three points are worth mention. First, the amendment is mandatory in character. It provides that the President "shall suspend" foreign aid if a recipient country takes American property without compensation, leaving the President with no discretion in the matter. This interpretation is supported by the amendment's final clause, which states further that "no other provision of this Act shall be construed to authorize the President to waive the provisions of this subsection." 20 Secondly, the amendment becomes operative when the foreign country either nationalizes, expropriates,

16 The proposal's legislative history is related in Lillich, supra note 4, at 407-14.

17108 ConG. REc. 15187 (1962).

1876 Stat. 260-61 (1962), 22 U.S.C. $\$ 2370$ (e) (Supp. IV, 1962).

19 Some of the questions are considered in Lillich, sipra note 4, at 414-22.

2076 Stat. 260-61 (1962), 22 U.S.C. 2370(e) (Supp. IV, 1962). 
or seizes ownership or control of American property, or imposes or enforces discriminatory taxes, exactions, or conditions having the same effect. This phraseology is broad enough to embrace both typical acts of expropriation and acts falling under the rubric of "creeping nationalization." While the language used does not specifically cover injuries caused by a foreign country's breach of contract, it is arguable that such a breach would fall thereunder. ${ }^{21}$

Finally, the amendment requires the foreign country to take steps to pay "equitable and speedy compensation for such property in convertible foreign exchange, as required by international law ....." Although there is an indication that the House equated this standard with the Department of State's traditional view requiring the payment of prompt, adequate, and effective compensation, ${ }^{22}$ contrary to some assertions, "equitable and speedy compensation" are not "words of particular meaning to international lawyers." 23 In view of the departure from standard terminology and the ambiguous legislative history, this writer had tentatively concluded that "the President is free to take a fairly liberal attitude toward the requirement of 'equitable' compensation." 24 Actually, the President interpreted the amendment fairly strictly in the one instance where it has been applied, a fact that did not prevent Congress from inserting the traditional standard when it revised the amendment last year.

\section{The 1963 REvisions}

The 1963 amendments to the Hickenlooper Amendment were facilitated by the Department of State's decision to try to live with the law rather than to seek its repeal. ${ }^{25}$ Indeed, with Secretary Rusk revising his views and agreeing that "the policy underlying that amendment is a very important one," 28 the revisions had smooth sailing. According to the Senate Committee on Foreign Relations, they were intended to "tighten the existing law somewhat, broaden its provisions, and provide the President in his discretion with the resources and experience of the Foreign Claims Settlement Commission." 27

21 Lillich, supra note 4 , at 416-18.

22 H.R. Rep. No. 1788, 87th Cong., 2d Sess. 30 (1962) [hereinafter cited as House REPORT].

23108 Cong. Rec. 13152 (1962) (Mr. Adair).

24 Lillich, supra note 4 , at 420.

25 Senate Hearings 273-75 (Mr. Bell).

26 Id. at 30 .

27 S. ReP. No. 588, 88th Cong., 1st Sess. 30 (1963) [hereinafter cited as Senate REPORT]. 


\section{A. Tightening the Amendment}

The original amendment called for the suspension of aid "provided under this Act," namely, the Foreign Assistance Act of 1961, as amended. When foreign aid to Ceylon was suspended, the Department of State, "to avoid hardship to the people of Ceylon," decided to continue a Food-for-Peace program of school lunches for 1,847,000 children daily, plus a nutrition program for 70,000 mothers and preschool children. The Department argued that "suspension of Food-for-Peace programs is not legally required as these programs are authorized under legislation other than the Foreign Assistance Act." 28

The Senate soon moved to close this humanitarian loophole. Its 1963 foreign aid bill inserted the phrase "or any other" before the word "Act." The intention of this amendment, according to the Senate Committee on Foreign Relations, was to "extend the sanctions of the section to such activities and agencies as Public Law 480, the Export-Import Bank, and the Peace Corps." ${ }^{29}$ A brief colloquy in the Senate between Senators Hickenlooper and Morse suggests that the Committee later excepted the Peace Corps and cultural exchanges from its blanket prohibition, ${ }^{30}$ and the subsequent Conference report states that the House agreed to the Senate provision with an amendment "specifically excepting assistance to any country through the Export-Import Bank in addition to the Peace Corps, assistance under the Mutual Education and Cultural Exchange Act of 1961, and famine or disaster relief under Public Law 480 from the provisions of the Foreign Assistance Act." ${ }^{31}$ Yet the bill as enacted follows the Senate's draft bill and requires the suspension of aid "provided under this or any other Act ...."

The Senate bill contained another provision tightening the amendment insofar as "creeping nationalization" is concerned. The original amendment became operative not only when American property actually was taken, but also when the recipient country imposed discriminatory taxes, exactions; or conditions which had the same effect. To these latter actions the Senate bill added "or has taken other actions," ${ }^{32}$ an open-end phrase designed to confirm that the

28 Press Release issued Feb. 8, 1963, by the Agency for International Development (AID), Department of State, reprinted in 2 InTERNATIONAL LEgal Materials 386, 391 (1963).

29 SENATE REPORT 30.

30109 Cong. REc. 20684 (daily ed. Nov. 13, 1963).

31 H.R. ReP. No. 1006, 88th Cong., 1st Sess. 27 (1963).

32 SENATE REPORT 67. 
amendment caught acts of so-called "wealth deprivation." 33 "The committee has added the phrase "other actions," " states the Senate report,

because it has been concerned over recurring reports of actions which certain governments are either proposing or initiating and which can perhaps best be described as creeping expropriation. These other actions include, for example, unusually high taxes which are perhaps not discriminatory in a technical sense but which are tantamount to confiscation or which at least raise a serious question of their confiscatory effect. The committee intends for confiscation to be construed broadly and not in a narrow technical sense. ${ }^{34}$

The House bill contained identical language for similar reasons. ${ }^{35}$ Although the provisions of the original amendment seemed broad enough to cover the acts envisaged ${ }^{36}$ rendering the additional phrase superfluous, the latter, which had the strong support of the International Economic Policy Association, ${ }^{37}$ was enacted into law. It has the merit of dispelling any possible doubt about the amendment's scope.

A final clarifying provision was designed to end speculation about the quantum of compensation required to satisfy the amendment's "equitable" standard. ${ }^{38}$ Although the Department of State in the Ceylon situation had interpreted the amendment to require "the prompt payment of compensation representing the full value of the property as required by international law," ${ }^{39}$ a construction in keeping with its usual approach to the question, ${ }^{40}$ both the House and Senate bills sought to nail down this interpretation by eliminating the word "equitable" and qualifying "compensation" by the clause "equivalent to the full value thereof." 41 The House report assumed that this change, which was enacted into law, only "confirms that the term 'equitable" compensation means compensation 'equivalent to the full value' of the property taken. Compensation which is equivalent to the full value must include all elements or interests of value that make up the total

33 Senate Hearings 553 (Senator Hartke). See also id. at 554.

34 SeNATE Repori 29. For a discussion of "creeping expropriation" and a dozen specific examples thereof, see the memorandum of Senator Hickenlooper printed in 109 Cong. Rec. 20695-96 (daily ed. Nov. 13, 1963).

35 H.R. Rep. No. 646, 88th Cong., 1st Sess. 31, 72 (1963).

36 Lillich, supra note 4, at 416-17.

37 Senate Hearings 386; House Hearings 1225.

38 See text accompanying note 24 supra.

3948 Dep't State Bull. 328 (1963). The International Economic Policy Association patronizingly stated that "AID properly applied this statutory standard in suspending assistance to Ceylon under section 620(e)." House Hearings 1226.

40 See, e.g., 3 HackWorth, Digest of International, LAW 656-57 (1942).

41 Senate Report 67; House Report 72. 
worth of the property." 42 Thus Congress has clarified the original Hickenlooper Amendment on this score and deprived the President of any opportunity to take a more liberal attitude on the compensation question should a future situation so warrant.

\section{B. Broadening the Amendment}

The original amendment became operative in the event of the nationalization or other taking of American property. Thus, it did not specifically cover injuries caused by a foreign country's breach of contract. This writer, however, took the position that "since the trend in the law of international claims is toward the recognition of such claims based upon some sort of 'taking,' it may be argued that certain breaches of contract fall within the first, and conceivably the second, heading." ${ }^{43}$ Argentina's annulment of operating contracts with several American oil companies raised this question in November 1963. ${ }^{44}$ Asked whether the Hickenlooper Amendment applied to the Argentine situation, its author replied that:

In my opinion, the answer to that question is "Yes." I believe the amendment of last year-the provision now in the law-could be extended, by proper interpretation, to cover such a situation of nullification of contracts, as compared with expropriation or seizure of physical property. ${ }^{4 \overline{5}}$

Nevertheless, he supported the Senate bill revising the original amendment by bringing it into effect whenever a foreign country "has taken steps to repudiate or nullify existing contracts or agreements" with United States nationals. ${ }^{46}$

The enactment of this provision ends any possible speculation. One must agree with Senator Morse's conclusion that:

The language from the old act, with the previous Hickenlooper amendment, plus the new language in the bill that has

42 H.R. ReP. No. 646, 88th Cong., 1st Sess. 31-32 (1963). Note the rather naive statement by the International Economic Policy Association that this change would "take valuation out of the vagaries of diplomatic negotiations and put it on some basis of fact." Senate Hearings 386. Most international lawyers familiar with valuation disputes would take the position that the nebulous concept of "full value" has very little factual basis.

43 Lillich, supra note 4 , at 417.

44 The Times (London), Nov. 12, 1963, p. 10, cols. 3-4.

45109 Cong. Rec. 20682 (daily ed. Nov. 13, 1963). Senator Morse, as usual, was more picturesque. "The State Department ought to be told to 'get on the ball' so far as the Chilean and Argentinean situations are concerned, and make perfectly clear to those governments that if the merits of the cases substantiate the allegation that they are in violation of the Hickenlooper amendment, aid will be stopped." Id. at 20685.

46 Sente Report 67. Although the House bill did not contain a comparable provision, the House readily accepted the Senate provision. H.R. REP. No. 1006, 88th Cong., 1st Sess. 27 (1963). 
come to the floor of the Senate from the committee, leaves no room for doubt that it covers nullification of contracts in which property values, as well as outright expropriation of property, are involved. ${ }^{47}$

\section{Involving the FCSC}

The Foreign Claims Settlement Commission (FCSC) is a federal administrative agency whose main function has been to adjudicate nationalization claims after the Department of State has concluded a lump sum settlement with a foreign country ${ }^{48}$ or after Congress has authorized the use of a foreign country's vested assets to pay claims against it. ${ }^{49}$ During the past ten years the FCSC has rendered thousands of awards and developed a considerable body of expertise concerning the valuation of property. ${ }^{50}$ Under his original draft bill in 1962, Senator Hickenlooper gave the FCSC "exclusive jurisdiction to determine the extent and amounts of any losses sustained by a national of the United States for the purposes of this subsection." ${ }^{21}$ The Senator considered it to be "the proper and appropriate impartial body to assess the value of the property in foreign countries," since the FCSC "already possesses the criteria, and has a history of evaluation of American property abroad seized by foreign countries." 52 Conceivably, the mandatory referral to the FCSC also was designed to prevent the President from circumventing the purpose of the Hickenlooper Amendment by a liberal construction of the compensation requirement.

This aspect of the Senator's proposal was not adopted. Instead, sole discretion in determining the matter was given to the President. Although, as the FCSC's Chairman has noted, "the amendment makes no provisions as to the determination of the facts of expropriation, the reasonableness under international law of the ensuing steps taken by the nation, or relief for the American property-owners," ${ }^{53}$ the President, using the State Department's Agency for International Develop-

47109 CoNG. REC. 20683 (daily ed. Nov. 13, 1963). Whether, as Senator Hickenlooper contends, it applies not only to the nullification of contracts "but also to the fruits of them" is a different matter. Id. at 20682.

48 See, e.g., Agreement With Bulgaria, July 2, 1963 [1963] 1 U.S.T. \& O.I.A. 969, T.I.A.S. No. 5387. This latest settlement agreement is analyzed in Lillich, The United States-Bulgarian Claims Agreement of 1963, 58 AM. J. INT'L L. 686 (1964).

49 See, e.g., 69 Stat. 562-70 (1955), 22 U.S.C. \$\$1631-(n) (1958).

50 See generally Lillich \& Christenson, Interanational Clatas : Therr Preparation and Presentarion 74-81 (1962); Lillich, The Foreign Claims Settlement Commission and the Protection of Foreign Investment, 48 IowA L. REv. 779 (1963).

51108 CoNG. REc. 7893 (1962). (Emphasis added.)

52 Ibid.

$53 \mathrm{Re}$, The Foreign Clains Settlement Commission: Its Functions and Jurisdiction, 60 MiCE. L. REv. 1079, 1096 n.90 (1962). 
ment (AID), experienced no great difficulties in applying the amendment to Ceylon. ${ }^{54}$ Nevertheless, Senator Hartke's 1963 draft bill contained a provision designed to "assist the President in valuation proceedings by utilizing the expert services of the Foreign Claims Settlement Commission of the United States to render an advisory valuation report to the President during the 6-month period." 55 This provision was adopted by the Senate ${ }^{56}$ and accepted by the House. ${ }^{57}$ In brief it authorizes the FCSC, should the President so request within seventy days after the foreign country's action, "to evaluate expropriated property, determining the full value of any property nationalized, expropriated, or seized, or subjected to discriminatory or other actions as aforesaid, for purposes of this subsection and to render an advisory report to the President within ninety days after such request." 58

Two points warrant emphasis here. First, as the conference report acknowledges, the provision authorizes, but does not require, the President to use the FCSC's services. ${ }^{59}$ Thus, unlike Senator Hickenlooper's 1962 version, the referral is discretionary and not mandatory. Second, even if the President should opt to use the FCSC, a most unlikely event, its report is not binding, but only advisory. ${ }^{60}$ As the Senator himself states, upon receipt of the FCSC's report, the President "would then make a determination as to whether or not the valuation set on the property abroad would be a reasonable valua-

54 See text accompanying note 28 supra.

55 Senate Hearings 553 (Senator Hartke). The Senate bill may be found in Senate RePort 67-68.

$56 I d$. at $29-30$.

57 Because the question of the valuation of expropriated property is important to the proper administration of section $620(\mathrm{e})$, expert advice on valuation, in appropriate cases, can measurably assist the parties in settling their difference and also assist the Department of State in the effective use of section 620 (e) to protest the legitimate interests of U.S. investors. For these reasons, the managers on the part of the House accepted the Senate amendment, noting that the Foreign Claims Settlement Commission has a skilled staff, experienced in the valuation of foreign property, and apparently is better equipped to advise the President on property valuations than any other agency. Should the President prefer to have some other agency assume this function, he is free to do so.

H.R. ReP. No. 1006, 88th Cong., 1st Sess. 28 (1963). (Emphasis added.)

5877 Stat. 387 (1963). (Emphasis added.) The provision also states that "unless authorized by the President, the Commission shall not publish its advisory report except to the citizen or entity owning such property. There is hereby authorized to be appropriated such amount, to remain available until expended, as may be necessary from time to time to enable the Commission to carry out expeditiously its functions under this subsection." Ibid. The final sentence was included, according to a memorandum of the International Economic Policy Association, "so that the Commission's report on any particular case requested by the President will not be delayed by the necessity of obtaining a congressional appropriation at the moment when the Commission's services are required." Senate Hearings 406.

59 See note 57 supra.

60 See text accompanying note 58 supra. 
tion or not." 61 While the provision is therefore much less restrictive than the one proposed in 1962, one cannot imagine the President, in reaching a determination which could terminate a multimillion dollar aid program, delegating even the initial step in the decision-making process to what its Chairman characterizes as "an independent and permanent tribunal." 62

\section{An Evaluation}

The Hickenlooper Amendment has been on the statute books for almost two years. Debates during the past session of Congress indicate that the House, ${ }^{63}$ the Senate, ${ }^{64}$ and the business community ${ }^{65}$ support the amendment as a sound and effective method of protecting American foreign investment abroad. Senator Keating has expressed what appears to be the general consensus:

It is my belief-and I have heard this from many official sources-that the Hickenlooper amendment has substantially strengthened the hand of our Government in dealing with other nations which are prepared to accept out [sic] aid with one hand and confiscate our business with the other. Although there was some opposition from the

61109 CoNG. REc. 20683 (daily ed. Nov. 13, 1963). Since the foreign country must take appropriate steps within "twenty days after the report of the Commission is received," the President would be faced with a relatively speedy determination. Also, in the event of an immediate referral to the FCSC, the ninety and twenty day periods might end seventy days before the termination of the six month period in which the foreign country can take corrective measures in the absence of such referral. To international lawyers familiar with the complexities of valuation, the time limits for both alternatives seem unrealistic.

62 Re, The Foreign Clains Settlement Conmission and International Claims, 13 SyracuSE L. Rev. 516, 520 (1962). Quaere: is the FCSC really a "permanent" body? See H.R. REP. No. 1006, 88th Cong., 1st Sess. 28 (1963).

63 "This requirement has been helpful in obtaining negotiated settlements of expropriations as well as preventing the taking of expropriatory actions in a number of countries. The more other nations are aware of this provision, the less likely it is that the provisions of section 620 (e) will have to be applied." H.R. REP. No. 646, 88th Cong., 1st Sess. 30 (1963).

64 "The committee has been gratified by the experience under section 620(e) since it was made a part of the law last year. At least one major expropriation case has been settled which, in the committee's judgment, probably would not have been settled in the absence of section $620(\mathrm{e})$. Several other expropriations or discriminatory actions have been avoided. In only one case has the section operated to suspend assistance." SENATE REPORT 30.

65 In the brief period since its enactment, section 620 (e) has been responsible for negotiated settlements in Brazil, and the prevention of expropriatory actions in Honduras, Panama, and other countries. The United States suspended aid to Ceylon under section 620(e), after exhaustive diplomatic efforts failed to achieve a settlement satisfying the standards required by the act and international law. General Clay's report commended section 620(e) as "especially helpful."

Senate Hearings 405 (memorandum of International Economic Policy Association). 
Government to the Hickenlooper amendment last year, I believe it plays a most constructive role in our aid program and in our foreign policy generally. ${ }^{66}$

The strength of this sentiment, particularly at a time when the entire foreign aid bill was undergoing its heaviest attack in years, evidently caused the administration to change its position on the Hickenlooper Amendment. Whereas in 1962 both President Kennedy and Secretary Rusk opposed the provision, ${ }^{67}$ one year later Mr. Rusk, agreeing that "the policy underlying that amendment is a very important one," concluded that "our experience thus far has meant that that amendment has been a good thing." 88 This unexpected change of view is surprising when one considers that, almost simultaneously, the Secretary was inveighing against congressional attempts to "legislate foreign policy," "9 and that President Johnson similarly assailed the foreign aid bill as reflecting "unfortunately, the growing tendency to hamstring Executive flexibility with rigid legislative provisions wholly inappropriate and potentially dangerous in a world of rapid change." 70 Indeed, the President singled out the Hickenlooper Amendment when he declared: "I wish to make clear now, for example, thatwhen a free and peaceful government is ever established in Cuba-I intend to exercise my authority to provide essential health, education and other assistance to the Cuban people, without waiting for a long and complex adjudication." 71

What is even more surprising about the Secretary's sudden conversion is the fact that it apparently was based upon a reconsideration of the supposed effectiveness of the amendment-which will be discussed below-to the exclusion of all other foreign policy considerations. This narrow approach to the Hickenlooper Amendment stands in marked contrast to the Department's 1962 declaration that "the interests of single citizens in matters of eminent domain are among the factors to be evaluated in the decision in formulating our foreign policy, but these interests should not control it." 72 Some of the factors which militate against the amendment and which have the same validity today as they did when first raised by the Department in 1962 are as follows:

e6 Senate Hearings 348.

67 See notes 12,13 supra.

68 Senate Hearings 30.

69 N.Y. Herald-Tribune, Nov. 9-10, 1963, p. 1, col. 7 (Int'l ed.).

70 N.Y. Herald-Tribune, Dec. 18, 1963, p. 1, col. 7 (Int'l ed.).

71 Ibid. Actually, the amendment does not apply to the Cuban situation, since it only covers actions of foreign countries taken "on or after January 1,1962 . . ." Moreover, the amendment permits the President to order the resumption of aid should he be satisfied that appropriate steps are being taken by the foreign country. 72 Hearings on S. 2996 Before the Senate Committee on Foreign Relations, 87th Cong., 2d Sess. 558 (1962). (Emphasis added.) 
First, the writing of this provision into the Foreign Assistance Act could make it appear that our aid programs are substantially motivated by a desire to protect U.S. private investment and that they are, in effect, tools of U.S. capital. . . .

Second, a vital, and often crucial, element of U.S. foreign policy is placed at the mercy of one unreasonable action by a foreign official, perhaps not even a member of the national government of that country. . . .

Third, the suggested amendment could also retard some of the economic and social reforms we seek in connection with our aid program, particularly in Latin America. . . .

Fourth, a requirement that aid be cut off under'the suggested circumstances may well commit our whole policy into the hands of one intransigent American citizen, whose actions could provoke expropriation and whose obstinacy could prevent a reasonable settlement. . . .

Fifth, the question of judging the reasonableness of the compensation offered is frequently difficult, as indicated by emient domain cases in our own courts. An ex parte decision by the United States that it does not agree with the value of the property judicially determined by a court at the situs of the property, is hardly calculated to win respect. . . .

Finally, flexibility, rather than a rigid rule, is required. In the administration of its programs, AID will judge the entire use of a country's resources. If a particular country is dissipating its major resources in unproductive actionsuch as the use of its foreign exchange to compensate for expropriated property-the aid given to such a country by the United States will reflect this fact.

The interests of the United States as a nation require the balancing of many factors, and the availability of our foreign assistance must depend on the same factors. ${ }^{73}$

Yet in 1963 the Department apparently ignored these and other objections to the amendment ${ }^{74}$ and supported it on the sole ground that it had proved an effective method of protecting private foreign investment. ${ }^{75}$

Putting aside the above general objections to the amendment, if indeed that is possible, the Department's position on the narrow

$7 \dot{s}$ Ibid.

74 See generally Lillich, The Protection of Foreign Investment and the Foreign Assistance Act of 1962, 17 RutGers L. REv. 405, 423-27 (1963).

75 It is worth noting that unlike Secretary of State Rusk, who was "happy" to endorse the amendment, Senate Fearings 29, AID Administrator Bell refused to give it his personal blessing. The only statement on the amendment which Congress could extract from him was the neutral comment that "we are recommending no change in the present legislation." Id. at 274. 
point of the amendment's effectiveness is open to question. What is the basis for its shared belief that, in the words of General Clay, "perhaps because of the Hickenlooper amendment, compensation has been offered for the private property taken over without the consent of the U.S. companies concerned, and the compensation which was offered was acceptable to the companies?" 76 Although the legislative history of the 1963 revisions of the amendment is peppered with references to its beneficial effect with respect to actual or threatened expropriations in Chile, ${ }^{77}$ Honduras, ${ }^{78}$ Panama, ${ }^{78}$ and Peru, ${ }^{80}$ no facts to support these assertions were brought forth. Indeed, what facts are available concerning Argentina, Brazil, Ceylon, and Indonesia-the four major instances where the amendment has come into play-indicate that its effect varies from marginal to negligible.

In Argentina six American oil companies had their contracts with the Government nullified November 1963 despite the efforts of Under Secretary of State Harriman to prevent the annulment. ${ }^{81}$ The Argentine Government, not unreasonably, took the position "that the companies could seek recourse in the courts if they disagreed with the decisions and actions taken." 82 The companies, estimating their investments at 397 million dollars, in contrast to a 200-300 milliondollar figure set by Argentina, currently are seeking judicial relief. ${ }^{83}$

The Brazilian expropriations, which generated the enactment of the original Hickenlooper Amendment, ${ }^{84}$ have been settled in a manner which at least avoids the necessity of invoking the amendment. Asked what role it played in Brazil, AID Administrator Bell replied:

In the Brazil case, thus far appropriate steps, satisfactory to the private firms concerned, have been taken. There have been two main instances. The International Telephone and Telegraph settled their case some months ago, and are receiving payment; and the American Foreign Power case . . . is still under negotiation but the company is satisfied that the negotiations that are underway are appropriate and in good faith and that they are moving in the right direction.

Senator Long. My impression is that with regard to Brazil, it has worked out very well. The fact that the State Department had no flexibility about the matter more or less

76 Id. at 646.

77109 Cong. Rec. 20683-85 (daily ed. Nov. 13, 1963).

78 House Hearings 1231.

79 Senate Hearings 405.

80109 Cong. REC. 20684 (daily ed. Nov. 13, 1963).

81 N.Y. Herald-Tribune, Nov. 12, 1963, p. 1, col. 7 (Int'l ed.).

82 Ibid.

83 N.Y. Herald-Tribune, Nov. 5, 1963, p. 2, col. 7 (Int'1 ed.). For Argentina's complaint and one company's reply, see 3 INT'L LEGAL MATERIALs 112, 292 (1964).

84 See text accompanying note 10 supra. 
helped a settlement of fair compensation. If it had flexibility the Brazilian Government might have continued to press us to let them go on expropriating those investments.

Mr. BELI. They might, Senator, that is correct.

As I say, it is hypothetical. But nevertheless you are quite right. $^{85}$

The IT\&T settlement, which reportedly involves payment over a twenty-five year period, ${ }^{86}$ apparently resulted less from the threat to apply the amendment than from an overall improvement in the Brazilian political situation. ${ }^{87}$ Moreover, according to one authority on foreign investment, a director and vice president of the Standard Oil Company of New Jersey, the settlement's terms do not warrant congressional self-congratulation. ${ }^{88}$

Insofar as Ceylon is concerned, the very fact that aid to that country had to be suspended demonstrates the amendment's failure to achieve its prime objective: the effective protection of private foreign investment. ${ }^{89}$ Ceylon refused to bow to diplomatic pressure to settle the claims of the two oil companies, ${ }^{90}$ pointing out that local remedies were available to the companies and that "the U.S. Government's decision [to suspend aid] cannot fail to impair the prospects of successful negotiation of a lump sum settlement." 91 In a public communiqué issued February 8, 1963, Ceylon stated that its "experience in this instance shows the reliance on foreign aid could entail some measure of surrender of a country's freedom of action in regard to the adoption

85 Senate Hearings 273-74.

86 N.Y. Times, May 29, 1963, p. 3, col. 7 (Int'1 ed.).

87 N.Y. Times, Jan. 30, 1963, p. 4, col. 1 (Int'l ed.).

$88 \mathrm{Mr}$. Emilio Collado concluded that:

the United States Government has probably acted to the long-run detriment of both private investment and economic development by its exaggerated acclaim for the settlements reached by several U.S. companies for properties in Brazil which had been seized or seemed likely to be acquired by governmental authorities. The managements of the companies concerned apparently felt that acceptance of the compensation offered was better than the practical alternatives facing them. But it should be remembered that these alternatives seemed to involve at best unreasonable governmental restraints which were likely to make profitable operation impossible; and the terms of compensation - which provide low valuation, partial down payment and decades for payment of the remainder-can only serve to incite the interest of nationalistic groups in other countries.

Collado, Economic Development Through Private Enterprise, 41 ForeIgN Afrarrs 708, 714 (1963).

80 The attitude of certain members of Congress seems confused on this point. Mr. Bell, for instance, had to remind Representative Adair that the objective was "not to take AID out of Ceylon but to get an appropriate settlement . . ." House Hearings 118.

90 See note 6 supra.

91 Public Communique issued Feb. 8, 1963, by the Government of Ceylon, reprinted in 2 International Legal Materials 393, 394 (1963). 
of policies which receive the full endorsement of its own nationals." 22 Moreover, the termination of aid did not cause Ceylon to change its attitude, for, as Mr. Bell told Congress, "today there is no forward progress whatever on the settlement of the claim of the oil companies." ${ }^{93}$ Indeed, once the United States had retaliated massively (and ineffectively), Ceylon proceeded to expropriate additional assets of the very same companies. ${ }^{84}$

Finally, the negotiations with Indonesia in May and June of 1963 over new oil concessions involved a situation where the Hickenlooper Amendment could have become operative. Informed of a report that the United States might terminate its aid if $_{i s}$ Indonesia expropriated the properties of American oil companies, ${ }^{95}$ the Indonesian Minister of Basic Industries rejoined that "if it were true and it contains a threat, then Indonesia is prepared to face it." ${ }^{96}$ In fact according to Mr. Wilson Wyatt, the special representative of the President for these negotiations, the Hickenlooper Amendment was mentioned to President Sukarno only in the context of its being a political fact of life. ${ }^{97}$ Whether one agrees with the Department of State that the eventual settlement bestows "great benefits" upon both the oil companies and Indonesia, ${ }^{98}$ or sides with the New York Times which characterized it editorially as another example of "what Sukarno wants, it seems, Sukarno gets," 99 it is difficult to separate out the effect of the amendment, or to understand how it could have been more effective

92 Ibid. Compare Lillich, supra note 74, at 424: "Other countries may view section 620 (e) as an indirect attempt to restrict their powers of eminent domain and thus consider it an unjustified interference in their internal affairs."

93 Senate Hearings 274. Indeed, Mrs. Bandaranaike recently reaffirmed that "our independence. . . is something that we cherish and are unwilling to barter for a mess of aid . . . " N.Y. Times, April 3, 1964, p. 4, col. 2 (Int'l ed.).

94 The Daily Telegraph (London), June 6, 1963, p. 20, col. 3.

95 See, e.g., N.Y. Times, May 29, 1963, p. 1, col. 2 (Int'l ed.).

96 N.Y. Herald-Tribune, June 1-2, 1963, p. 2, col. 5 (Int'1 ed.). President Sukarno's reaction to these reports is indicated by his remark, "To hell with your aid!" N.Y. Times, March 26, 1964, p. 2, col. 4. See also N.Y. Times, May 4, 1964, p. 5 , col. 3 .

97 House Hearings 1584. State).

98 Id. at 1589 (statement of Mr. Abram Chayes, Legal Adviser, Department of

99 N.Y. Times, June 4, 1963, p. 6, col. 2 (Int'l ed.).

Faced with the possibility of complete expropriation, the companies have signed an agreement which nationalizes their refining, distribution and marketing facilities in Indonesia within the next 15 years under a complicated compensation plan. In return, they retain their right to continue their $\$ 250$ million-a-year crude-oil production and export business for at least 20 years under a contract giving Indonesia 60 per cent of their profits.

Ibid. Reports of the contracts signed in September 1963 stress the fact that they permit Indonesia to nationalize the local facilities of the companies after twelve years without paying compensation. See, e.g., N.Y. Herald-Tribune, Sept. 28-29, 1963, p. 6, col. 4 (Int'l ed.). While technically accurate, such reports do fail to give sufficient weight to other aspects of the "package" which favor the companies involved. 
than a firm diplomatic reminder of Congress' attitude made in the absence of such a statute.

One may conclude from the above cursory survey that the Hickenlooper Amendment played a marginal role in three instances of expropriation and perhaps even a negative one in a fourth case. In addition, from a broader perspective than mere property-protection, it contains the potential ingredients to infect United States relations with many foreign countries. "The possibility of the outright repeal of the section appears remote, however, since from a political standpoint a Congressman's vote for repeal would be tantamount to a vote against God or motherhood." 100 This last sentence, written over a year ago, has been validated by the 1963 amendments to the provision. What, then, can be done in the way of remedying its many defects?

The only remedial change in the amendment which now might obtain congressional approval would be one which makes its application discretionary and not mandatory. This single change would eliminate many, if not all, of the problems discussed above. True, there are members of Congress who lay great stress upon the amendment's automatic character, believing that its binding effect on the President actually strengthens his hand in negotiations with foreign countries. ${ }^{101}$ However, at least in 1962, some members took a different view, ${ }^{102}$ and other sections of the Foreign Assistance Act calling for the termination of aid in certain situations permit a waiver by the President if he finds such aid to be in the national interest. ${ }^{103} \mathrm{Re}-$ vision of the Hickenlooper Amendment in this fashion would not seriously weaken either the belief abroad that the United States is determined to protect its foreign investments or their actual protection. Yet it would restore to the President the flexibility he needs to balance this objective with others in formulating overall United States foreign policy toward countries which are embroiled in social, economic, and political change. Governor Harriman's admonition, if not heeded, may well return to haunt the halls of Congress. ${ }^{104}$

100 Lillich, supra note 74 , at 426 .

$101 \mathrm{My}$ impression has been that as long as you had the discretion to say that our national interest required that aid be continued countries just waited until they found you tied on a vote in the United Nations or in some important international matter and put the pressure on you to back down.

I heard both business people and your [AID] representatives in the field feel this way about it-that if you have no discretion about the matter, you have to tell them: "If you expropriate this property the President can't continue this aid, Congress won't let him. Here is a law that says that."

Senate Hearings 275 (Senator Long).

102 See Lillich, supra note 74, at 411-13.

103 See, e.g., 76 Stat. 260 (1962), 22 U.S.C. \$2370c (Supp. IV, 1962).

104 For an excellent comment by an experienced diplomat which supports the thesis of this Article, see Brown, Problems in Trying To Use Aid as an Instriment of Political Pressure, to be published in 1964 Procendings of the American Soc'y OF INTERNATIONAI $L$. 